Article

\title{
Prediction of Soil Carbon Fractions Using a Field Spectroradiometer Equipped with an Illuminating Contact Probe
}

\author{
Ann-Marie Fortuna ${ }^{1, *}$, Patrick J. Starks ${ }^{1}$, Amanda M. Nelson ${ }^{1,2} \mathbb{D}$ and Jean L. Steiner ${ }^{1,3}{ }^{\mathbb{D}}$ \\ 1 Grazingland Research Laboratory, USDA-ARS, El Reno, OK 73036, USA; Patrick.Starks@usda.gov (P.J.S.); \\ amanda.nelson@usda.gov or amnelso888@gmail.com (A.M.N.); jlsteiner@ksu.edu (J.L.S.) \\ 2 National Center for Alluvial Aquifer Research, USDA-ARS, Stoneville, MS 38776, USA \\ 3 Department of Agronomy, Kansas State University, Manhattan, KS 66506, USA \\ * Correspondence: Ann-Marie.Fortuna@usda.gov
}

Received: 14 September 2019; Accepted: 24 October 2019; Published: 28 October 2019

\begin{abstract}
This research compared the accuracy of laboratory reference measurements of soil C and $\mathrm{N}$ fractions with soil reflectance spectra acquired using a portable field spectroradiometer with an illuminating contact probe. Soil samples were taken from eight, 1.6 ha watersheds, located in El Reno, Oklahoma on native warm season grasslands and agronomic managements with landform complexes serving as replicates within and among treatments. Soil samples were taken from $0-30-\mathrm{cm}$. Measurements included total soil organic carbon (TSOC), total soil nitrogen (TSN), residual C of acid hydrolysis (RCAH), and particulate organic matter C (POMC) and $N(P O M N)$. Soil reflectance in the 350 to $2500 \mathrm{~nm}$ region was correlated with individual laboratory measurements. Each reference dataset was divided into model development data $(70 \%)$ and model validation data (30\%). Calibrated models were applied to validation datasets. Statistical analysis revealed that prediction efficiencies of soil reflectance models were highly quantitative. Coefficients of determination $\left(R^{2}\right)$ were near $1(\geq 0.90)$ and ratios of predicted values to the measured standard deviation (RPD) were $>2$, indicative of good predictive models. The field spectroradiometer enabled us to parameterize soil spatial variability and soil reflectance measurements, reducing the resources required to acquire edaphic measurements.
\end{abstract}

Keywords: spectroradiometer; particulate organic matter fraction; soil organic matter fractions; mineral associated organic fractions

\section{Introduction}

Pools of soil carbon and nitrogen reflect both dynamic and inherent edaphic properties [1]. Currently, total soil organic carbon (TSOC) and nitrogen (TSN) are used to assess the fertility of soils and as a measure of soil health - "the capacity of a soil to function within ecosystem boundaries to sustain biological productivity, maintain environmental quality, and promote plant and animal health" [2]. As a result, a plethora of rapid tests measuring a range of $C$ and $N$ fractions have been employed to assess the effects of land management, climate, and soil constituents [3]. Although, TSOC and TSN are universally used to assess the longer term effects of land use and climate variability in terms of years or decades, these measurements are not appropriate for rapid assessment of shifts in land management or climate within or among seasons or to evaluate the presence/absence of specific functional groups made up of $\mathrm{C}, \mathrm{H}, \mathrm{O}$, and $\mathrm{N}$ that reflect the source of plant and animal inputs and their state of decomposition and incorporation into soil organic matter $[4,5]$.

Several chemical and physical measurements have been successfully employed for the purpose of fractionating soil $\mathrm{C}$ and $\mathrm{N}$ into meaningful pools that include the residual carbon of acid hydrolysis $(\mathrm{RCAH})$, particulate organic matter carbon (POMC), and nitrogen (POMN) [6,7]. Particulate organic 
matter (POM) contains a greater proportion of biologically available $\mathrm{C}$ and $\mathrm{N}$ relative to $\mathrm{RCAH}$ and contributes significantly to seasonal nutrient turnover $[5,8,9]$. The POM fraction is equivalent to the organic fraction associated with the sand-sized soil separates retained on a $53 \mu \mathrm{m}$ sieve after residues $>2 \mathrm{~mm}$ have been removed and soil has been dispersed using a reciprocating shaker and $5 \%$ sodium polyphosphate [10]. In agroecosystems managed as grassland and cropland and not receiving organic inputs containing humic and aromatic materials (i.e., compost, animal waste or biochar), the POM fraction is dominated by plant residues that turnover rapidly at half the rate of TSOC, making it an appropriate indicator for rapid assessment of shifts in land management or climate [11].

In contrast, acid hydrolysis analysis was designed to isolate what is known as the resistant pool of C [6]. This fraction is resistant to microbial decomposition and is not considered biologically active. In the rooting zone of agroecosystems ( $\sim-30 \mathrm{~cm}$ deep), RCAH has an estimated turnover rate of 1200 to 1400 years, constitutes $50-60 \%$ TSOC, and contributes to soil physical properties, such as water holding capacity and $C$ sequestration $[4,8,9]$. Previous research has estimated the resistant $C$ fraction to be between $\sim 30 \%$ and $80 \%$ of TSOC at a $\sim 0$ to $30 \mathrm{~cm}$ depth across a range of soil textures, climatic conditions, and agroecosystems [4,8,12-14]. Estimating the size of the resistant fraction relative to TSOC and POM provides information in respect to the amount of $C$ that would have to be added or lost prior to measuring a change in TSOC [8].

Neither measurement of RCAH or POM provides information with respect to the biochemical constituents contained in each fraction. Acid added to soils during the hydrolysis analysis ensures that the majority of $C$ remaining is highly aromatic, humified, and aliphatic $[5,15]$. However, there is evidence in the literature that bioavailable lignin can persist after the acid digest is complete and that the type(s) of plant material and organic inputs present influence the above artifact associated with this protocol [16]. The POM C and N constituents and their turnover are even more diverse and variable than those of RCAH, because the POM fraction is less chemically restrictive, eliminating constituents on the basis of dispersion and sieve size alone.

Measurements of reflectance in various parts of the electromagnetic spectrum, such as in diffuse reflectance Fourier transform infrared spectroscopy (DR-FTIR, 2500-10,000 nm) or less specialized measurements in the mid-infrared (MIR, 2500-25,000 nm), near-infrared (NIR, 800-2500 nm), and visible (400-800 nm) wavelength regions, are invaluable, as each technique provides information with respect to specific functional groups in plant and soil organic matter as well as edaphic properties [17-20]. Using a range of wavelengths described above, it is possible to trace the incorporation of plant material into various fractions of $\mathrm{C}$ and $\mathrm{N}$ in soils that are associated with specific and overlapping mineral fractions, such as the light fraction (organic components of soil that float on the surface of a liquid with a density in the range of 1.60 to $2.00 \mathrm{~g} \mathrm{~cm}^{-3}$ as defined by Elliott and Cambardella [21], the particulate organic matter fraction, and the resistant $C$ fraction $[19,22]$.

This research is a step towards using in situ field spectroradiometry for the determination of various soil $\mathrm{C}$ and $\mathrm{N}$ fractions. Our work compares the accuracy of laboratory reference measurements to predictive equations acquired using a portable field spectroradiometer. Soil reflectance spectra were obtained from air-dried soil passed through a $2 \mathrm{~mm}$ sieve after which subsamples were left unground and ground. The goal of this experiment was to use the soil reflectance data to develop (calibrate) and validate predictive models for measurement of total soil organic carbon (TSOC); total soil nitrogen (TSN); C that is resistant to acid hydrolysis reactions (RACH); and particulate organic matter C (POMC) and N (POMN). The soils used in this study were collected from the Water Resources and Erosion (WRE) watershed site established in 1976 at the United States Department of Agriculture, Agriculture Research Service (USDA-ARS), Grazinglands Research Laboratory in El Reno, Oklahoma, USA, and which maintains paddocks representative of diversified adaptive crop livestock systems. Since its inception, research on the WRE has addressed "agricultural sustainability, climate change, ecosystem services, and natural resource conservation at the watershed or landscape scale". Currently, the project contributes to two national projects the USDA-ARS Conservation Effects Assessment Project (CEAP) and the Long-Term Agro-Ecosystem Research (LTAR) network. The calibrated models generated via 
spectroradiometry will be used to continue to monitor shifts in soil C and $\mathrm{N}$ (indicators of soil health) resulting from adaption of management practices designed to address climatic variation.

\section{Materials and Methods}

\subsection{Watershed Descriptions and Soil Sampling}

The study area was in southern tall grass prairie (STGP) prior to the establishment of the field site in 1976. The three dominant grasses in the southern tall grass prairie managements were big bluestem (Andropogon gerardi), little bluestem (Schizachyrium scoparium), and Indian grass (Sorghastrum nutans). Four of the eight watersheds were cropped to winter wheat (WW) (Triticum aestivum) and four remained in southern tall grass prairie (Figure 1). Each watershed is $80 \mathrm{~m}$ wide, $200 \mathrm{~m}$ long, and is surrounded by berms, ridges, and natural boundaries which form a drainage area of 1.6 ha ( $4 \mathrm{ac})$. The longitudinal slope of the watersheds faces west and varies between $3 \%$ and $4 \%$. Watersheds 1 and 2 are in historically unplowed TGP. Watershed 5 was in winter wheat planted to summer forages most years prior to 2000 and under low-disturbance management (no or minimal tillage, disking, harrowing, etc.) throughout the experiment (Figure 1). A class I soil survey was conducted at the study site in August of 2018 [23]. The two soil series that covered the greatest area within the watersheds were Bethany (fine, mixed, super active, thermic Pachic Paleustolls) and Renfrow (fine, mixed, super active, thermic Udertic Paleustolls) with smaller interfingering areas of Norge (fine-silty, mixed, active, thermic Udic Paleustolls) [24], (Figure 1). All three soil series were silt loams derived from undifferentiated Dog Creek Shale and Blaine Formations of the El Reno Group [25]. No carbonates were located within the 0 to $30 \mathrm{~cm}$ depths sampled. Therefore, total or whole soil $\mathrm{C}$ was equivalent to TSOC. The average annual temperature is $14.9^{\circ} \mathrm{C}$, with a high of $21.7^{\circ} \mathrm{C}$ and a low of $8.2^{\circ} \mathrm{C}$, and the average yearly rainfall is $869 \mathrm{~mm}[26]$.
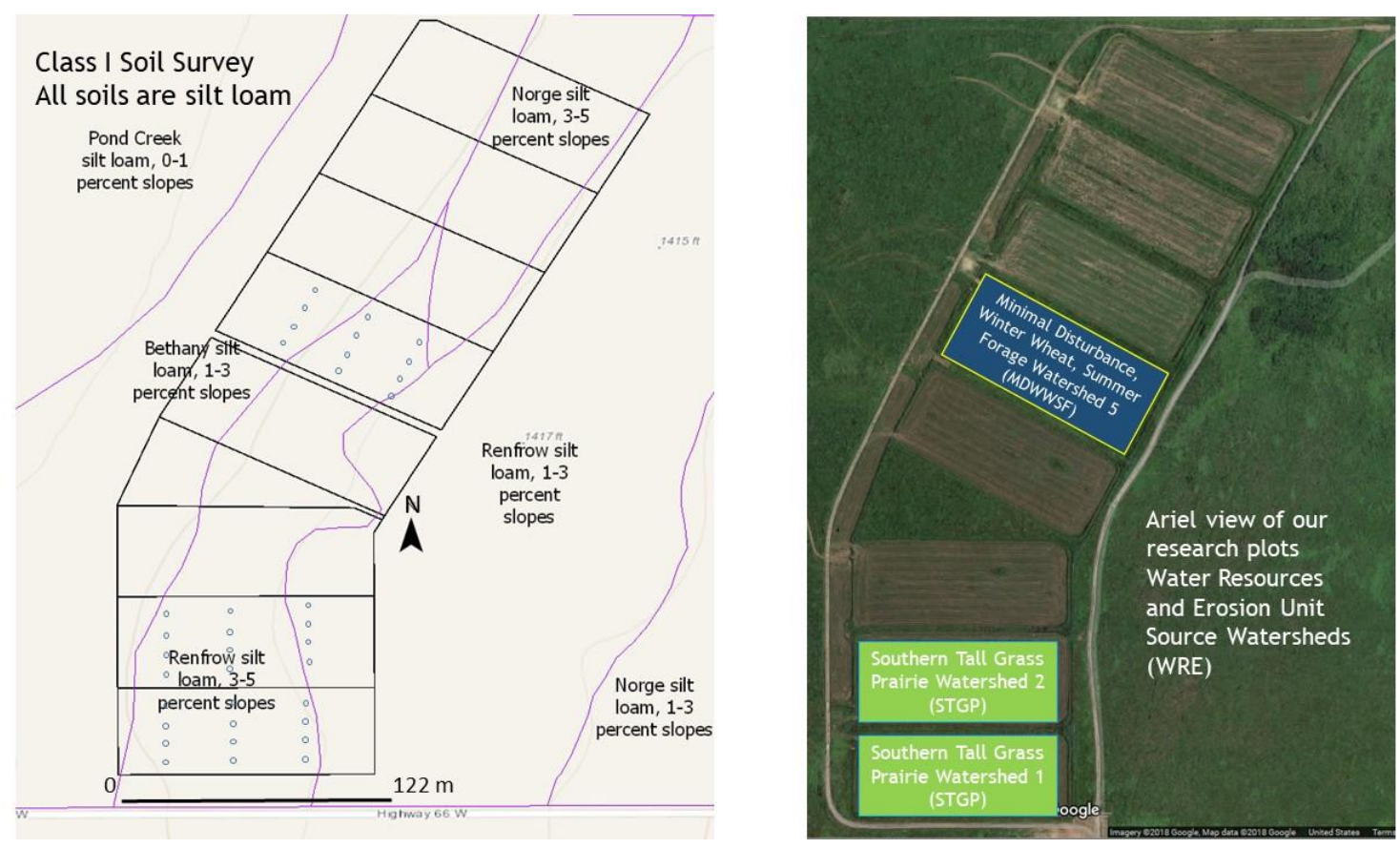

Figure 1. Four watersheds remained in southern tall grass prairie from 1976-2018. Circles on the class I soil survey each represent a $4.57 \mathrm{~m} \times 3.9 \mathrm{~m}$ square sampling zone and are approximately but not exactly placed at the GPS points.

Soil samples were collected on three watersheds (1, 2, and 5). A Garmin ETrex 10 Outdoor Handheld GPS Navigation Unit-AW16 (Garmin Ltd., Olathe, KS, USA) was used to record the location 
of the four corners of each of the $4.57 \mathrm{~m}(15 \mathrm{ft}) \times 3.9 \mathrm{~m}(12.8 \mathrm{ft})$ sampling zones. Each sampling zone was replicated four times at each landscape position capturing the catena effect, slopes, and aspects within each watershed (Figure 1). Creation of the replicated zones enabled us to define landform complexes that were needed to create uniform zones of management representing the variable characteristics affecting production within the larger watersheds. Four replicate sampling zones were located at each landscape position: the riser, side slope, and toe slope (i.e., 12 sampling zones on each watershed, 36 in total for watersheds 1, 2, and 5). A Giddings (Windsor, CO, USA) Probe, Model HDGSRPS, fitted with Poly-Ethylene Terephthalate Glycol (PTEG) soil tube liners (inert to chemicals and contaminants) was used to take four random, replicate soil cores, $5 \mathrm{~cm}$ in diameter to a $30 \mathrm{~cm}$ depth, in each of the four $4.57 \mathrm{~m} \times 3.9 \mathrm{~m}$ replicate sampling zones located at each of the three landscape positions for a total of 48 soil cores per watershed. Watersheds 1,2, and 5 were sampled and a total of 144 soil cores $(30 \mathrm{~cm})$ were taken. Each soil core was capped at both ends and immediately frozen in a freezer chest with the temperature set at $-18{ }^{\circ} \mathrm{C}$. Frozen soil cores were cut into three separate depths $(0$ to 5,5 to 15 , and 15 to $30 \mathrm{~cm}$ ) using a miter saw. After samples were removed from the cut soil liners, each of the 4 duplicate soil depths taken from one of the four replicate sampling zones at a given landscape position on a given watershed were thawed, thoroughly mixed, and passed through a $2 \mathrm{~mm}$ sieve. Sieving removed plant residue allowed for further mixing and homogenizing of soil samples. After combining the 4 sample core depths taken from a replicate sampling zone and landscape position of a watershed, there were 4 samples at each of the three depths for a total of 12 composite soil samples at a given landscape position on a single watershed. There were 36 composite soil samples representing all landscape positions and soil depths per watershed. Finally, there were 108 composite soil samples that represented all landscape positions, soil depths, and watersheds to be further processed.

\subsection{Soil Analysis}

Gravimetric water content was determined for each of the 108 soil samples. The texture of each soil sample was determined by the soil hydrometer (ASTM 152H) method. Sub-samples of each soil sample were dried at $60^{\circ} \mathrm{C}$ in a Fisherbrand ${ }^{\mathrm{TM}}$ Isotemp ${ }^{\mathrm{TM}}$ general purpose heating and drying oven (Fisher Scientific, Waltham, MA, USA). After oven drying, each of the 108 soil samples were further sub-sampled for POM and acid hydrolysis analysis. Fractionation of POM consisted of weighing a $25 \mathrm{~g}$ sample of oven dry soil into a $250 \mathrm{~mL}$ bottle and dispersing via $100 \mathrm{~mL}$ of sodium hexametaphosphate $\left(\left(\mathrm{NaPO}_{3}\right)_{6}\right)$ solution $\left(5 \mathrm{~g} \mathrm{~L}^{-1} \mathrm{diH}_{2} \mathrm{O}\right)$ followed by shaking on a reciprocating shaker for $15 \mathrm{~h}$. After dispersion, the soil slurries were placed on a $53 \mu \mathrm{m}$ sieve $(270 \mathrm{mesh})$. The portion of the soil samples remaining on the sieve were rinsed with distilled water $\left(\mathrm{diH}_{2} \mathrm{O}\right)$ until water passing through the sieve was clear. The rinsed POM material was then transferred into an aluminum weigh boat and oven dried at $60^{\circ} \mathrm{C}$ for $24 \mathrm{~h}$. Dried POM samples were then ground with a mortar and pestle to pass a $250 \mathrm{~mm}$ sieve.

Residual C of acid hydrolysis (RCAH) was isolated using a $1 \mathrm{~g}$ subsample of each oven-dried soil added to a $50 \mathrm{~mL}$ digestion tube in which twenty-five milliliters of $6 \mathrm{~mol} \mathrm{~L}^{-1} \mathrm{HCl}$ was added [4] and the tube vortexed briefly. A DigiPREP HT Digestion block (SCP SCIENCE, Champlain, NY, USA) was used to heat the samples to $115^{\circ} \mathrm{C}$, a manifold was placed over top of the tubes, and the block was maintained at temperature for $18 \mathrm{~h}$. Samples were cooled to room temperature, centrifuged, and the majority of the acid was decanted off without loss of the remaining soil material after which $50 \mathrm{~mL}$ of deionized water $\left(\mathrm{diH}_{2} \mathrm{O}\right)$ was added to each digestion tube. The tubes were then vortexed, allowed to settle for $24 \mathrm{~h}$, centrifuged, and the liquid decanted off. This process was repeated three times. The soils were then transferred to aluminum weigh tins and oven dried at $60{ }^{\circ} \mathrm{C}$ for $24 \mathrm{~h}$, cooled, and weighed immediately to calculate the mass loss.

Oven-dried whole soil, POM, and RCAH were weighed and ground using a mortar and pestle $(<0.25 \mathrm{~mm})$. Half-gram samples of oven-dried soil, POM, and RCAH were then weighed for total TSN, SOC, POMN, POMC, and RCAH analysis on a 928 Series LECO C/N Analyzer (Leco Corporation, St. Joseph, MI, USA) via dry combustion. 


\subsection{Spectroradiometry Measurements}

One hundred soil samples $(n=100)$ were identified for spectral analysis from each of the following groups: whole soil, ground whole soil, POM, and RCAH. Eight sample scans were removed because one of the correlated measurements (whole soil C, whole soil N, POM C, POM N or RCAH) was determined to be an outlier. As was previously mentioned above, soil samples were taken from three watersheds at three landscape positions; each landscape position contained four sampling zones. The soils were randomly sampled from four replicate sampling zones at three depths. Field samples were then brought into the lab, composited, mixed, and sieved. A subsample of the 108 whole soil samples remained unground. The POM RCAH and a sub-sample of whole soil was ground using a mortar and pestle to pass a $250 \mathrm{~mm}$ sieve and weighed. Each $\sim 1 \mathrm{~g}$ sample, irrespective of the type of sample, was uniformly packed into a $25 \mathrm{~mm}$, black circular sample cup such that the entire surface of the sample cup was covered. Samples were scanned three times at $1 \mathrm{~nm}$ spectral resolution over the 350 to $2500 \mathrm{~nm}$ region using a Spectral Evolution PSR +3500 (Spectral Evolution Inc., Haverhill, MA, USA) spectroradiometer equipped with an illuminating contact probe. The contact probe was mounted on a tripod to maintain a consistent angle of view and height above the sample. This configuration ensured that the sensor field-of-view was filled by the soil sample. White reference panel (Labsphere Inc., North Sutton, NH, USA) scans were made prior to each set of six samples. Reflectance factors (R) were automatically calculated by the spectrometer software by dividing each sample scan by the most recent reference panel scan. The three scans for a given sample were averaged and then converted into pseudo-absorbance by calculating the $\log (1 / \mathrm{R})$. The resulting averaged scan for a given sample was paired with the appropriate unground or ground whole soil C or N, POM C or N, or RCAH measurement. Each dataset (whole soil, ground soil, POM, RCAH) was input separately into WinISI II version 1.5 (FOSS North America, Eden Prairie, MN, USA) chemometric software for the development and evaluation of equations to predict whole or ground soil N and C, POM N and C, and RCAH. Prior to analysis, each dataset was randomly separated into calibration (70\%) and validation (30\%) subsets.

\subsection{Calibration and Statistical Treatment of Spectroradiometry Data}

The spectral data underwent further mathematical transformations in WinISI II by taking the first derivative and smoothing the data over a $20 \mathrm{~nm}$ span and applying standard variate normal scatter correction and de-trending algorithms. After the mathematical transformations, modified partial least squares (MPLS) was used to develop the prediction (i.e., calibration) equations. During calibration, the software performs several passes through the dataset and removes outliers to produce the best possible equation. Objective functions used to evaluate the equations included the standard error of the calibration (SEC), coefficient of determination $\left(R^{2}\right)$, standard error of the cross-validation (SECV), 1 minus the variance ratio (1-VR), and the ratio of the standard deviation to the standard error of cross-validation (RSC). Less than $7 \%$ of the total spectral scans were removed from all calibration and validation analyses. The final number of samples ( $n$-size) taken from each reference measurement dataset to produce an individual calibration or validation equation is also reported within the footnotes of tables containing the calibration and validation results.

The calibration equations were then applied to the validation dataset, the results of which were evaluated using the standard error of the prediction (SEP), bias, the SEP corrected for bias (SEPC), $R^{2}$, and ratio of the standard deviation to the standard error of prediction (RPD). (The RPC and RSD are comparable terms and are differentiated here to represent the calibration and validation datasets, respectively.) According to Terhoeven-Urselmans et al. [27], good prediction equations should have a correlation coefficient $(r)>0.9$, a slope between 0.9 and 1.1, be inclusive, and an RSC $>2$. Satisfactory prediction equations should have an $r \geq 0.8$, slope between 0.8 and 1.2, be inclusive, and an RSC between 1.4 and 2.0, inclusive. Datasets not producing satisfactory to good calibrations were evaluated for outliers, which were removed and the dataset re-analyzed. (The final $n$-size of the validation dataset is also reported.) With the exception of the bias statistic, values of the validation dataset objective 
functions were interpreted in the same manner, where applicable, as the comparable calibration statistics. Ideally, biases should be near zero.

\subsection{Statistical Analyses}

A randomized complete block design was superimposed across the study site allowing us to test interactions among management and landscape effects (land management, landscape position, and depth) and to obtain means and standard errors for each soil measurement. We analyzed differences in total soil N, POMN, TSOC, POMC, RCAH, sand, silt, and clay resulting from differences in land management, landscape position, and depth using a completely randomized three-factor factorial analysis of variance in SAS PROC MIXED, SAS statistical analysis software (SAS Institute, Cary, NC, USA). Means were determined to be significantly different using a Bonferroni-adjusted $p$-value of 0.05 . Pearson's rank correlation was used to test for monotonic trends among TSN, POMN, TSOC, POMC, RCAH, sand, silt, and clay using SAS PROC CORR.

\section{Results and Discussion}

\subsection{Soil Properties and Organic Fractions}

Concentrations of TSOC, TSN, and RCAH were not statistically different within a given depth in the two southern tall grass prairie watersheds (STGP1 and STGP2) (Table 1). The minimally disturbed, winter wheat, summer forage watershed (MDWWSF) soils contained significantly less TSOC and RCAH within the 0 to $5 \mathrm{~cm}$ depth relative to both the STGP1 and 2 watersheds (Table 1). The STGP1 and 2 watersheds contained more than $40 \%$ greater TSOC and $\sim 50$ greater RCAH relative to the MDWWSF watershed at the 0 to $5 \mathrm{~cm}$ depth. There were nearly no statistical differences in measured concentrations among the three watersheds below $15 \mathrm{~cm}$ (Table 1). Our concentrations of whole total soil carbon followed a similar pattern as soil organic matter (SOM) concentrations measured via loss on ignition [28] from a set of soil samples taken in 2004 on Watersheds STGP1 and 2. These earlier SOM measurements and the current experiment verify that the majority of variability in SOM and soil C occurs within the top $10 \mathrm{~cm}$ of soil and drops off dramatically beyond $15 \mathrm{~cm}$.

Table 1. Treatment (southern tall grass prairie watersheds ${ }^{1,2}$ (STGP) 1 and 2 and the minimal disturbance, winter wheat summer forage ${ }^{3}$ (MDWWSF) watershed 5, by depth soil interactions for total soil nitrogen ${ }^{4}$ (TSN), total soil organic $C^{5}$ (TSOC), residual C of acid hydrolysis ${ }^{6}$ (RCAH), ${ }^{7}$ Clay, and ${ }^{8}$ Sand.

\begin{tabular}{|c|c|c|c|c|c|c|c|}
\hline Treatment $^{1}$ & $\begin{array}{l}\text { Depth } \\
\text { (cm) }\end{array}$ & $\begin{array}{l}\text { Total } \\
\text { Soil N }\end{array}$ & $\begin{array}{l}5 \text { Total Soil } \\
\text { Organic C }\end{array}$ & $\begin{array}{l}{ }^{6} \text { Residual C of } \\
\text { Acid Hydrolysis }\end{array}$ & RCAH/TSOC & ${ }^{7}$ Clay & ${ }^{8}$ Sand \\
\hline & & $\left(\mathrm{g} \mathrm{kg}^{-1}\right)$ & $\left(\mathrm{g} \mathrm{kg}^{-1}\right)$ & $\left(\mathrm{g} \mathrm{kg}^{-1}\right)$ & $(\%)$ & $(\%)$ & $(\%)$ \\
\hline \multirow{3}{*}{${ }^{1}$ STGP1 } & $0-5$ & $2.60^{\mathrm{a}}$ & $29.8^{\mathrm{a}}$ & $18.3^{a}$ & 61 & $18^{\mathrm{c}}$ & $28^{a}$ \\
\hline & $5-15$ & $1.34^{\mathrm{b}}$ & $15.4^{\mathrm{bc}}$ & $9.09^{b}$ & 59 & $21^{b}$ & $22^{b}$ \\
\hline & $15-30$ & $0.94^{\mathrm{c}}$ & $11.4^{\mathrm{c}}$ & $6.88^{b c}$ & 60 & $26^{a}$ & $21^{b}$ \\
\hline \multirow{3}{*}{2 STGP2 } & $0-5$ & $2.43^{\mathrm{a}}$ & $27.9^{\mathrm{a}}$ & $17.6^{\mathrm{a}}$ & 63 & $20^{\mathrm{b}}$ & $23^{b}$ \\
\hline & $5-15$ & $1.46^{\mathrm{b}}$ & $16.7^{\mathrm{b}}$ & $8.97^{b}$ & 54 & $24^{\mathrm{a}}$ & $24^{b}$ \\
\hline & $15-30$ & $1.06^{\mathrm{c}}$ & $12.6^{\mathrm{c}}$ & $8.03^{b}$ & 64 & $26^{\mathrm{a}}$ & $21^{\mathrm{b}}$ \\
\hline \multirow{3}{*}{${ }^{3}$ MDWWSF5 } & $0-5$ & $1.69^{a b}$ & $18.9^{b}$ & $9.93^{b}$ & 52 & $20^{\mathrm{b}}$ & $28^{a}$ \\
\hline & $5-15$ & $1.10^{c}$ & $12.1^{\mathrm{c}}$ & $6.78^{\mathrm{c}}$ & 56 & $20^{b}$ & $31^{\mathrm{a}}$ \\
\hline & $15-30$ & $1.00^{\mathrm{c}}$ & $10.7^{c}$ & $6.18^{\mathrm{c}}$ & 56 & $20^{b}$ & $21^{\mathrm{a}}$ \\
\hline
\end{tabular}

Statistically significant differences (univariate two-way ANOVA in PROC GLM, post hoc: Fischer LSD) are indicated by different lower case letters within each column; treatment management $\times$ depth interaction $(p<0.05)$.

Carbon in RCAH constituted between $52 \%$ and $64 \%$ of TSOC and varied due to the watershed management. The RCAH fraction constituted $52 \%$ of the TSOC in the MDWWSF watershed and $\sim 60 \%$ in watersheds STGP1 and STGP2. Other researchers have also reported similar increases in resistant $C$ in soils under grassland management relative to row crop management $[4,5]$. The resistant 
C fraction is assumed to contain a minimal amount of biologically active $C$, although it may still contain residual lignin [4]. Resistant $C$ improves soil water holding capacity and contributes to aggregate formation $[4,5]$.

Although the three watersheds were individually mapped as silt loams, there were significant differences in the percentage of sand and clay fractions varying by watershed and soil depth. The agronomically managed watershed (MDWWSF) contained a greater percent of sand relative to STGP1 and STGP2 (Table 1). In contrast, the clay content was significantly higher in the lower depths of the STGP1 and STGP2 watersheds relative to the MDWWSF (Table 1). Particulate organic matter N did not vary due to the watershed management and constituted between $1.26 \%$ and $1.65 \%$ of TSN (Table 2). In contrast, POMC was significantly greater in the STGP1 and STGP2 watersheds comprising between $17 \%$ and $18 \%$ of TSOC relative to the MDWWSF (15\%).

Table 2. Measurements of particulate organic matter nitrogen ${ }^{2}$ (POMN), POMN as a fraction of total soil nitrogen ${ }^{3}$ (TSN), POMN as a percent of total soil $\mathrm{N}^{4}(\%$ of TSN), particulate organic matter carbon ${ }^{5}$ (POMC), total soil organic $\mathrm{C}^{6}$ (TSOC) and POMC as a percent of total soil organic $\mathrm{C}^{7}$ (\% of TSOC).

\begin{tabular}{ccccccc}
\hline & ${ }^{2}$ POMN & ${ }^{3}$ TSN & ${ }^{4} \mathbf{\%}$ of & ${ }^{5}$ POMC & ${ }^{\mathbf{6}}$ TSOC & ${ }^{\mathbf{7} \% \text { of }}$ \\
\hline Treatment $^{\mathbf{1}}$ & $\mathbf{~} \mathbf{~ g ~ k g}^{\mathbf{1}}$ & $\mathbf{g ~ k g}^{\mathbf{1}}$ & TSN & ${ }^{\mathbf{8}} \mathbf{g ~ k g}^{\mathbf{- 1}}$ & $\mathbf{g ~ k g}^{\mathbf{1}}$ & TSOC \\
\hline STGP1 & 158 & 1.63 & 0.97 & $3.23^{\mathrm{a}}$ & 18.8 & 17.2 \\
STGP2 & 180 & 1.65 & 1.09 & $3.43^{\mathrm{a}}$ & 19.1 & 18.0 \\
MDWWSF5 & 149 & 1.26 & 1.18 & $2.08^{\mathrm{b}}$ & 13.9 & 15.0 \\
\hline
\end{tabular}

\footnotetext{
${ }^{1}$ Southern tall grass prairie watersheds 1 and 2, (STGP1 and STGP2) and the minimal disturbance, winter wheat, summer forage watershed 5 (MDWWSF5). ${ }^{8}$ Statistically significant differences (univariate two-way ANOVA in PROC GLM, post hoc: Fischer LSD) are indicated by different lowercase letters within each column; treatment management $\times$ depth interaction $(p<0.05)$.
}

Particulate organic matter N, POMC, TSN, TSOC, and RCAH were all positively correlated with one another $(p<0.01)$ (Table 3). Specifically, correlation coefficients descriptive of POMC and N fractions and TSOC and TSN were $r=0.98$ and 0.99 , respectively. As mentioned previously, POM C and $\mathrm{N}$ make up a measurable and biologically significant percentage of TSOC and TSN. Therefore, POM C and N are significantly positively correlated with TSOC and TSN (Table 3). The correlation coefficients ranged from $r=0.73$ to 0.77 . The resistant fraction, RCAH, was significantly $(p<0.01)$ positively correlated with TSOC $(r=0.88)$ and POMC $(r=0.76)$. Percent silt was positively $(p<0.01)$ correlated with RCAH $(r=0.28)$, TSOC $(r=0.27)$, TSN $(r=0.25)$, and POMC $(p<0.05, r=0.21)$. In contrast, the percentage of clay content had a significant $(p<0.01)$ but negative effect on all $\mathrm{C}$ and $\mathrm{N}$ fractions with correlation coefficients ranging from $r=-0.33$ to -0.43 . These results corroborate the findings of other researchers who have used naturally occurring, stable carbon isotopes and "prebomb" carbon to date $C$ associated with silt and clay fractions and found that $C$ associated with silt is older than $C$ typically associated with the clay fraction $[4,5]$. The mechanisms that drive such reactions are still unclear and merit further investigation. Clays may be physically and or chemically protecting more biologically available $\mathrm{C}$ fractions containing plant material that would not interact with the silt fraction and, as a result, would undergo further decomposition. Future applications of in situ field analyses of intact soil pedons using a spectroradiometer equipped with an illuminating contact probe may provide further insight into how mineral and organic soil fractions interact. 
Table 3. Correlations between edaphic properties and soil nitrogen $(\mathrm{N})$ and carbon $(\mathrm{C})$ fractions.

\begin{tabular}{ccccccccc}
\hline & POM_N $^{1}$ & POM_C $^{2}$ & TSN $^{3}$ & TSOC $^{4}$ & RCAH $^{5}$ & Sand & Clay & Silt \\
\hline POM_N & 1.00 & $0.98^{* *}$ & $0.74^{* *}$ & $0.73^{* *}$ & $0.71^{* *}$ & 0.13 & $-0.40^{* *}$ & 0.16 \\
POM_C & & 1.00 & $0.77^{* *}$ & $0.77^{* *}$ & $0.76^{* *}$ & 0.07 & $-0.38^{* *}$ & $0.21^{*}$ \\
TSN & & & 1.00 & $0.99^{* *}$ & $0.87^{* *}$ & 0.08 & $-0.43^{* *}$ & $0.25^{* *}$ \\
TSOC & & & & 1.00 & $0.88^{* *}$ & 0.04 & $-0.41^{* *}$ & $0.27^{* *}$ \\
RCAH & & & & & 1.00 & -0.04 & $-0.33^{* *}$ & $0.28^{* *}$ \\
Sand & & & & & & 1.00 & $-0.41^{* *}$ & $-0.73^{* *}$ \\
Clay & & & & & & & 1.00 & $-0.32^{* *}$ \\
Silt & & & & & & & & 1.00 \\
\hline
\end{tabular}

* significant at $p<0.05$; ${ }^{*}$ Significant at $p<0.01 .{ }^{1}$ POMN: particulate organic matter nitrogen; ${ }^{2}$ POMC: carbon particulate organic matter; ${ }^{3}$ TSN: total soil nitrogen; ${ }^{4}$ TSOC: total soil organic $C ;{ }^{5}$ RCAH: Residual C of acid hydrolysis.

\subsection{Calibration and Validation of Reflectance-Based Algorithms}

Prior to spectral analysis, each dataset (i.e., whole ground soil, whole unground soil, ground POM, and acid hydrolysis) was separated into a calibration and validation dataset using a random function (see Sections 2.3 and 2.4 and Tables 4 and 5 for the exact number of samples used in the calibration and validation models for a given measurement). The calibration datasets typically contained $70 \%$ of the original data and the remaining $30 \%$ of the data was used for validation. As was previously mentioned, less than $7 \%$ of all spectral scans were considered outliers and removed. Coefficients of determination $\left(R^{2}\right)$ —or the degree of the relationship among two variables—represent the predictive capability of a model. Weak quantitative predictions can be inferred from $R^{2} \mathrm{~s}$ ranging from 0.66 to 0.81 , while $R^{2} \mathrm{~s}$ between 0.82 and 0.90 represent good predictions and $R^{2} \mathrm{~s}>0.91$ are considered excellent, i.e., highly quantitative predictions [29]. The coefficients of determination of the calibration models for unground and ground whole soil $\mathrm{N}$ and $\mathrm{C}$ were highly correlated, $R^{2}=0.99$ (Table 4), indicating that the additional preparatory work of grinding did not improve the calibrations. Coefficients of determination for ground POM N and C were $R^{2}=0.94$ and 0.97 , respectively, whereas $R^{2}$ for RACH was the lowest but still an excellent fit $\left(R^{2}=0.92\right)$. Researchers in Canada developed models for TSN, TSOC, and POM C and POM N using eight soils under varying land uses, obtaining similar coefficients of determination [20]. The ratios of the standard deviation to the standard error of cross-validation (RSC) were all above three with the exception of the ground POM N (2.84).

Table 4. Calibration models developed for the prediction of whole and ground soil carbon (TSOC) and nitrogen (TSN), particulate organic matter carbon (POMC) and nitrogen (POMN), and residual C of acid hydrolysis (RCAH). ${ }^{1}$

\begin{tabular}{|c|c|c|c|c|c|c|c|}
\hline \multirow{2}{*}{$\begin{array}{l}\text { Calibration } \\
\text { Statistics }^{2}\end{array}$} & \multicolumn{2}{|c|}{ Whole Soil Ground } & \multicolumn{2}{|c|}{ Whole Soil Unground } & \multicolumn{2}{|c|}{ POM Ground } & \multirow{2}{*}{$\frac{\text { RCAH }}{\text { C }}$} \\
\hline & $\mathbf{N}$ & $\mathrm{C}$ & $\mathbf{N}$ & $\mathrm{C}$ & $\mathbf{N}$ & $\mathrm{C}$ & \\
\hline$n$ size & 61.0 & 61.0 & 56.0 & 55 & 62.0 & 61.0 & 67.0 \\
\hline Mean & 1.49 & 17.0 & 1.32 & 14.9 & 137 & 2.29 & 10.6 \\
\hline SD & 0.65 & 7.43 & 0.50 & 5.36 & 141 & 1.94 & 5.20 \\
\hline SEC & 0.08 & 0.87 & 0.03 & 0.30 & 35.6 & 0.33 & 1.50 \\
\hline$R^{2}$ & 0.99 & 0.99 & 0.99 & 0.99 & 0.94 & 0.97 & 0.92 \\
\hline SECV & 0.16 & 1.88 & 0.12 & 1.36 & 49.5 & 0.57 & 1.72 \\
\hline $1-\mathrm{VR}$ & 0.94 & 0.94 & 0.94 & 0.94 & 0.88 & 0.91 & 0.89 \\
\hline RSC & 3.96 & 3.96 & 4.14 & 3.95 & 2.84 & 3.38 & 3.03 \\
\hline
\end{tabular}

\footnotetext{
${ }^{1}$ Soil ground (total $n$ size $=99$, validation $\mathrm{N} n$ size $=25$, validation $\mathrm{C} n$ size $=27$ ), whole soil unground (total $n$ size $=86$, validation $\mathrm{N} n$ size $=18$, validation $\mathrm{C} n$ size $=17), \mathrm{POM}$ ground (total $n$ size $=70$, validation $\mathrm{N} n$ size $=$ 20 , validation $\mathrm{C} n$ size $=21) .{ }^{2} \mathrm{SEC}=$ standard error of the calibration; $R^{2}=$ coefficient of determination; $\mathrm{SECV}=$ standard error of the cross-validation; $1-\mathrm{VR}=1$ minus the variance ratio; $\mathrm{RSC}=$ ratio of the standard deviation to the standard error of cross-validation; RPD = ratio of the standard deviation to the standard error of prediction. Mathematical treatments: reflectance spectra $(R)$ transformed from percent reflectance to pseudo-absorbance via $\log (1 / \mathrm{R}) 1$ st derivative, gap $=20 \mathrm{~nm}$, no smoothing standard normal variate transform and detrending. Prior to analysis: each dataset (whole ground soil, whole unground soil, ground POM, acid hydrolysis) was separated into a calibration and validation dataset using a random function (see Section 2.3). Calibration datasets typically contained $70 \%$ of the original data and $30 \%$ for validation.
} 
All seven calibration models were highly successful in predicting the validation measurements. The coefficients of determination were all at or above 0.90 as were the slopes of the measured versus predicted regression lines (Table 5). The goodness of fit was also demonstrated by the similarities between the standard error of the prediction (SEP) and the SEP corrected for bias (SEP(C)). The bias measurements themselves were all close to zero with the exception of ground POMN (Table 5). Finally, the ratios of the standard deviation to the standard error of prediction (RPD) were all $>2$ (six of the seven models were $>3.3$ ) the threshold considered for a model to be quantitatively predictive [27]. Our RPD values are comparable to those of Zhang et al.'s [20] as previously described above.

Table 5. Validation statistics for whole and ground soil carbon (TSOC) and nitrogen (TSN), particulate organic matter carbon (POMC) and nitrogen (POMN), and residual C of acid hydrolysis (RCAH). ${ }^{2}$

\begin{tabular}{|c|c|c|c|c|c|c|c|}
\hline \multirow{2}{*}{$\begin{array}{l}\text { Validation } \\
\text { Statistics }\end{array}$} & \multicolumn{2}{|c|}{ Whole Soil Ground } & \multicolumn{2}{|c|}{ Whole Soil Unground } & \multicolumn{2}{|c|}{ POM Ground } & \multirow{2}{*}{$\frac{\text { RCAH }}{\mathrm{C}}$} \\
\hline & $\mathbf{N}$ & $\mathrm{C}$ & $\mathbf{N}$ & $\mathrm{C}$ & $\mathbf{N}$ & $\mathrm{C}$ & \\
\hline Slope & 0.90 & 0.97 & 0.98 & 1.04 & 0.97 & 1.06 & 0.98 \\
\hline$R^{2}$ & 0.92 & 0.98 & 0.91 & 0.94 & 0.94 & 0.90 & 0.91 \\
\hline SEP & 0.20 & 0.98 & 0.15 & 1.52 & 35.4 & 0.73 & 1.61 \\
\hline Bias & -0.03 & 0.15 & -0.05 & -0.41 & 6.37 & 0.11 & -1.05 \\
\hline $\operatorname{SEP}(\mathrm{C})$ & 0.20 & 0.99 & 0.15 & 1.51 & 35.6 & 0.74 & 1.25 \\
\hline RPD & 3.31 & 7.57 & 3.26 & 3.52 & 3.98 & 2.65 & 3.23 \\
\hline
\end{tabular}

${ }^{1}$ Whole soil ground (total $n$ size $=99$, validation $\mathrm{N} n$ size $=25$, validation $\mathrm{C} n$ size $=27$ ), whole soil unground (total $n$ size $=86$, validation $\mathrm{N} n$ size $=18$, validation $\mathrm{C} n$ size $=17$ ), $\mathrm{POM}$ ground (total $n$ size $=70$, validation $\mathrm{N} n$ size $=20$, validation $C n$ size $=21) .{ }^{2}$ Slope: $=$ measured versus predicted slopes of the regression lines; SEP = standard error of the prediction; $\mathrm{SEP}(\mathrm{C})=\mathrm{SEP}$ corrected for bias; $\mathrm{RPD}=$ ratio of the standard deviation to the standard error of prediction ( $\mathrm{RPD}=\mathrm{SD} / \mathrm{SEP})$; good predictions: correlation coefficient $>0.9$, regression coefficient (slope) between 0.9 and 1.1, inclusive, and RSC $>2$; satisfactory predictions: correlation coefficient $\geq 0.8$, regression coefficient between 0.8 and 1.2, inclusive, and RSC between 1.4 and 2.0, inclusive, and RSC between 1.4 and 2.0, inclusive.

\subsection{Comparison of Spectral Data in Soil C and N Fractions}

The wavelengths that had the greatest influence on spectral scans of ground and unground soil samples were identical. Therefore, ground and whole soil scans could not be distinguished from one another. The correlogram of the correlation and reflectance at a given wavelength (Figure 2) contains unground whole soil. Obtaining comparable results from unground soil reduces the amount of time required to process samples and suggests that accurate in situ field measurements are likely to be possible at this LTAR location and others. The reflectance spectra of whole soil samples were equally useful in predicting the $\mathrm{C}$ and $\mathrm{N}$ constituents. Similarly, the POM spectral scans were equally useful in the prediction of the $\mathrm{C}$ and $\mathrm{N}$ constituents in this fraction.
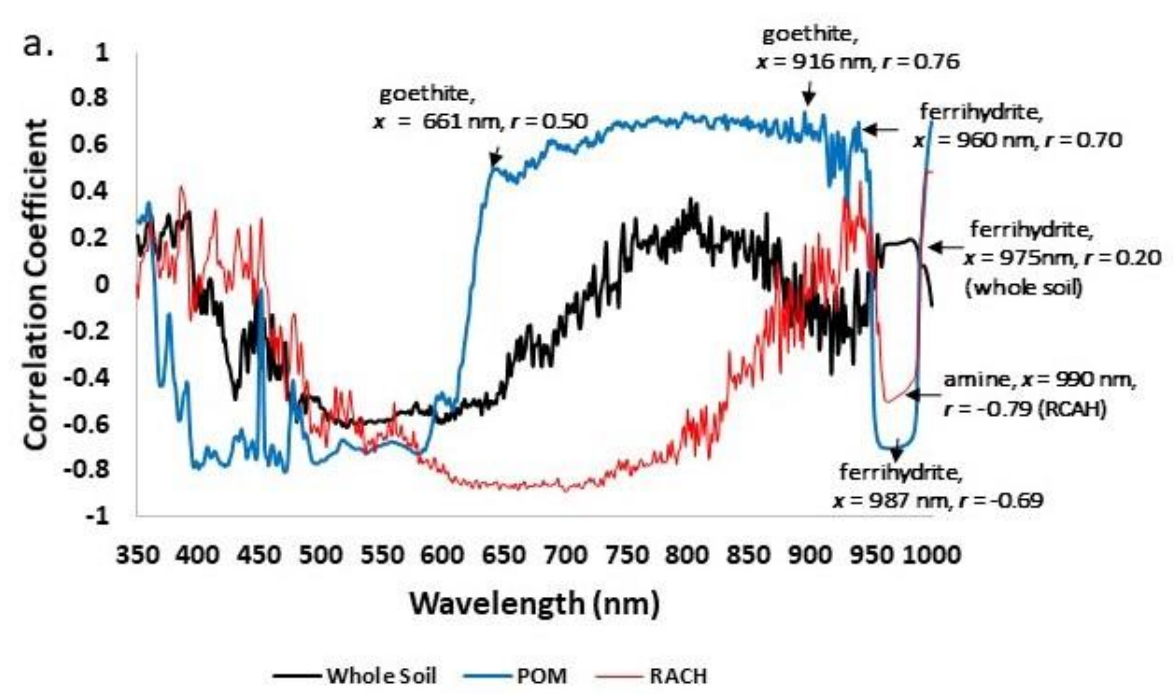

Figure 2. Cont. 

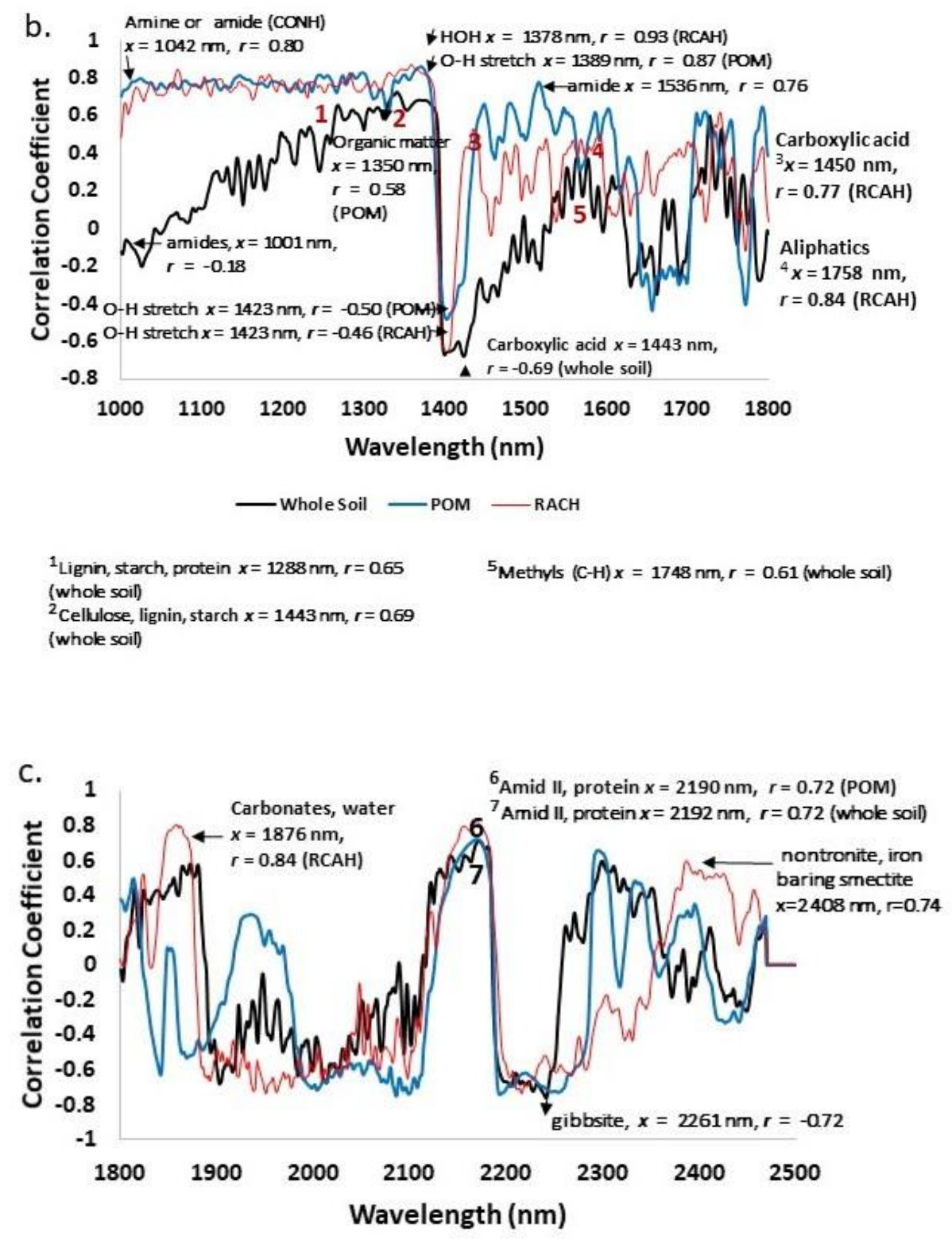

Whole Soil —POM - RACH

Figure 2. (a-c) Correlograms of the correlation ( $r, y$-axis) and reflectance at a given wavelength ( $x$-axis) with whole soil ( $\mathrm{C}$ or $\mathrm{N}$ ), POM ( $\mathrm{N}$ or $\mathrm{C}$ ), or $\mathrm{RACH}$ containing wavelengths that correlated with mineral and organic components. Measurements were taken using a spectroradiometer. Correlograms of the correlation and reflectance at a given wavelength were compared to the published literature $[17,30]$.

Figure 2 is a correlogram of the correlation ( $r, y$-axis) and reflectance at a given wavelength $(x$-axis) for whole soil (C or N), POM ( $\mathrm{N}$ or $\mathrm{C}$ ), or RACH. The correlogram contains wavelengths that are correlated with mineral and organic components [17,30]. Prior to the adaption of routine spectral analyses of soil, numerous studies had previously applied a number of laborious physical, chemical, and biological measures to verify the resistance, age, and size of organic fractions associated with soil separates (sand, silt, and clay) [5,31,32]. Our data verify that spectroradiometry can be correlated to a range of soil $\mathrm{C}$ and $\mathrm{N}$ fractions, reducing the number of chemometric measurements required. Although a significant portion of resistant $\mathrm{C}$, estimated via acid hydrolysis (RACH), was determined to be made of humic substance, Plante et al. [5] concluded that the fraction also contained plant-derived compounds. Correlating measured carbon fractions representing the continuum of $C$ in the soil, such 
as POMC, whole soil $\mathrm{C}$, and $\mathrm{RACH}$, with spectroradiometer readings enables researchers to rapidly derive information about organo-mineral associations in soil [33,34]. Particularly, the visible (VIS) and NIR ranges that provide quantitative information with respect to mineral and organic constituents often without prior preparation of soil samples via grinding for example [30,33].

Whole soil, POM, and RCAH contained iron bearing minerals (Table 6 and Figure 2), all three dominant soil series in the watershed treatments contained iron oxides and active to super-active clay minerals [24]. Whole soil spectral scans (solid, black lines) were positively correlated with ferrihydrite, $(\mathrm{Fe}-\mathrm{O}-\mathrm{OH})(x=975 \mathrm{~nm}, r=0.20)$ and more negatively correlated with gibbsite, $\gamma-\mathrm{Al}(\mathrm{OH})_{3}(x=2261$ $\mathrm{nm}, r=-0.77$ ). The POM fraction (solid, gray line) containing the sand size separates was positively correlated with three wavelengths that potentially correspond to Goethite, $\mathrm{FeO}(\mathrm{OH}),(x=661 \mathrm{~nm}, r$ $=0.50 ; x=916 \mathrm{~nm}, r=0.76 ; x=960 \mathrm{~nm}, r=0.70$ ) and was negatively correlated with ferrihydrite, $(\mathrm{Fe}-\mathrm{O}-\mathrm{OH})(\mathrm{x}=987 \mathrm{~nm}, r=-0.69)$. The RACH fraction (hatched, black line) was positively correlated with nontronite, an iron enriched smectite $(x=2408 \mathrm{~nm}, r=0.74)$. These minerals have been previously shown to chemically and physically protect plant-derived and humic $C$ compounds $[4,5,33,34]$.

Table 6. Correlation (r, y-axis) and reflectance at a given wavelength (x-axis) with whole soil (C or N), particulate organic matter ( ${ }^{1}$ POM C or N), or residual C of acid hydrolysis ${ }^{2}$ (RACH).

\begin{tabular}{|c|c|c|c|c|c|c|}
\hline \multirow[b]{2}{*}{$\begin{array}{l}\text { Potential Edaphic } \\
\text { Constituent }\end{array}$} & \multicolumn{2}{|c|}{ Whole Soil } & \multicolumn{2}{|c|}{${ }^{1}$ POM } & \multicolumn{2}{|c|}{${ }^{2} \mathrm{RCAH}$} \\
\hline & $\begin{array}{c}\text { Wavelength } \\
(\mathrm{nm})\end{array}$ & $\begin{array}{c}{ }^{3} \text { Corr } \\
(r)\end{array}$ & $\begin{array}{c}\text { Wavelength } \\
(\mathrm{nm})\end{array}$ & $\begin{array}{c}{ }^{3} \text { Corr } \\
(r)\end{array}$ & $\begin{array}{c}\text { Wavelength } \\
(\mathrm{nm})\end{array}$ & $\begin{array}{c}{ }^{3} \text { Corr } \\
(r)\end{array}$ \\
\hline goethite $^{4}$ & & & 661 & 0.50 & & \\
\hline goethite & & & 916 & 0.76 & & \\
\hline goethite & & & 960 & 0.70 & & \\
\hline ferrihydrate & 975 & 0.20 & & & & \\
\hline ferrihydrate & & & 987 & $(-0.69)$ & & \\
\hline amine & & & & & 990 & 0.79 \\
\hline amides & 1001 & 0.18 & & & & \\
\hline $\mathrm{CONH}$ & & & 1042 & 0.80 & & \\
\hline lignin, starch, protein & 1288 & 0.65 & & & & \\
\hline organic matter & & & 1350 & 0.58 & & \\
\hline cellulose, lignin, starch & 1361 & 0.72 & & & & \\
\hline $\mathrm{HOH}$ & & & & & 1378 & 0.93 \\
\hline $\mathrm{O}-\mathrm{H}$ stretch & & & 1389 & 0.87 & & \\
\hline O-H stretch & & & 1423 & -0.46 & 1423 & 0.46 \\
\hline carboxylic acid & 1443 & -0.69 & & & & \\
\hline carboxylic acid & & & & & 1450 & 0.77 \\
\hline amides & & & 1536 & 0.76 & & \\
\hline methyls (C-H) & 1748 & 0.61 & & & & \\
\hline aliphatics & & & & & 1758 & 0.84 \\
\hline carbonates, water & & & & & 1876 & 0.84 \\
\hline amid II, protein & 2192 & 0.72 & 2190 & 0.72 & & \\
\hline gibbsite & 2261 & $(-0.72)$ & & & & \\
\hline nontronite & & & & & 2408 & 0.74 \\
\hline
\end{tabular}

${ }^{4}$ All mineralogical constituents are italicized.

Scans from each measured variable-whole soil, POM, and RCAH—contained wavelengths that potentially represented varying organic $C$ compounds that included plant-derived fractions, such as carbohydrates and cellulose, and constituents of humified fractions (Table 6 and Figure 2). Previous research reported spectral overlap in the "greatest influence infrared range" among NIR C measurements associated with the sand, silt, and clay fractions [19]. The POM fraction was positively correlated with organic matter, $\mathrm{x}=1350 \mathrm{~nm}(r=0.58)$. Whole soil scans contained four wavelengths associated with organic $C$. Two were positively correlated $x=1288 \mathrm{~nm}(r=0.65)$ with lignin, starch and 
protein and $x=1748 \mathrm{~nm}(r=0.61)$ correlated with methyls $(\mathrm{C}-\mathrm{H})$. The third was negatively correlated $x$ $=1443 \mathrm{~nm}(r=-0.69)$ with carboxylic acid. In contrast, RCAH was positively correlated with carboxylic acid $x=1450 \mathrm{~nm}(r=0.77)$ as well as with aliphatic constituents, $x=1758 \mathrm{~nm}(r=0.84)$. A similar positive correlation of carboxyl constituents in the resistant $C$ fraction and negative correlation in whole soil C was reported by Rossel and Hicks [30].

In a number of wavelengths associated with $\mathrm{N}$ compounds that included amines (general formula $\mathrm{CO}-\mathrm{NH}$ ), amides, $\mathrm{RC}(\mathrm{O}) \mathrm{NH}_{2}$, and proteins, $\mathrm{RCH}\left(\mathrm{NH}_{2}\right) \mathrm{COOH}$ was present in scans associated with whole soil, POM, and RACH samples. Amines were positively correlated with the RACH fraction $(x=990 \mathrm{~nm}, r=0.79)$. Amides were positively correlated with whole soil $(x=1001 \mathrm{~nm}, r=0.18)$. The same wavelength corresponding to protein was found in whole soil $x=2192 \mathrm{~nm}(r=0.72)$ and POM $(x=2190 \mathrm{~nm}, r=0.72)$ but was not present in RACH samples. There was also an overlap of organic $\mathrm{N}$ and C compounds in whole soil scans at $x=1288 \mathrm{~nm}(r=0.65)$ representative of lignin, starch, and protein compounds and POM at $x=1042 \mathrm{~nm}(r=0.80 \mathrm{~nm})$ associated with CONH. Previous research reported spectral overlap among NIR N and C:N measurements associated with the sand, silt, and clay fractions [19].

\section{Conclusions}

This study combined geospatial and a landform element classification with spectroradiometry to codify the collection of soil data at variable scale within a single field experiment. Creation of replicated zones within each watershed enabled us to statistically determine the effects of land management on the variability of measured $\mathrm{C}$ and $\mathrm{N}$ fractions. The goal of this research was to create models to predict unground or ground whole soil $\mathrm{N}$ and $\mathrm{C}, \mathrm{POM} \mathrm{N}$ and $\mathrm{C}$, and $\mathrm{RCAH}$ with the intent of tracking land management at a local watershed scale, regionally, and on a national level via the LTAR network. Measured $\mathrm{C}$ and $\mathrm{N}$ fractions were used to successfully calibrate and predict concentrations of TSOC, TSN, RCAH, and POMC and N using a portable field spectroradiometer fitted with an illuminating contact probe. Soils in the winter wheat, summer forage management contained significantly less measured and predicted TSOC, TSN, RCAH, and POMC and N relative to soils in watersheds managed as southern tall grass prairies within the 0 to $15 \mathrm{~cm}$ depth. As a step towards using in situ field spectroradiometry for determination of various soil $\mathrm{C}$ and $\mathrm{N}$ fractions, this research successfully compared the accuracy of laboratory reference measurements to predictive equations developed from soil reflectance spectra, of processed soils, acquired using a portable field spectroradiometer. Our initial efforts to parameterize the inherent spatial variability of these watersheds in order to determine the effects of land management on soil health were successful. After calibration and determination of inherent soil variability at a given scale, a smaller subset of soil samples can be collected $(\sim 10 \%$ of the original sample size for sample calibration and validation) to determine if sample variations in $C$ and $\mathrm{N}$ fractions are due to the adaption of land management designed to address climatic variation.

Author Contributions: A.-M.F. wrote the manuscript; P.J.S., A.M.N. and J.L.S. edited the manuscript and contributed their intellectual property.

Funding: Research was funded by the United States Department of Agriculture.

Acknowledgments: This research contributed to the Conservation Effects Assessment Project and is a contribution of the USDA-ARS Southern Plains Long-Term Agroecosystem Research Site.

Conflicts of Interest: The authors declare no conflict of interest for this study.

Disclaimers: Mention of trade names or commercial products in this publication is solely for the purpose of providing specific information and does not imply recommendation or endorsement by the US Department of Agriculture. The US Department of Agriculture (USDA) prohibits discrimination in all its programs and activities on the basis of race, color, national origin, age, disability, and where applicable, sex, marital status, familial status, parental status, religion, sexual orientation, genetic information, political beliefs, reprisal, or because all or part of an individual's income is derived from any public assistance program. USDA is an equal opportunity provider and employer. 


\section{References}

1. Fortuna, A.-M.; Honeycutt, C.W.; Vandemark, G.; Griffin, T.S.; Larkin, R.P.; He, Z.; Wienhold, B.J.; Sistani, K.R.; Albrecht, S.L.; Woodbury, B.L.; et al. Links among nitrification, nitrifier communities, and edaphic properties in contrasting soils receiving dairy slurry. J. Environ. Qual. 2012, 41, 262-272. [CrossRef] [PubMed]

2. Doran, J.W.; Parkin, T.B.; Doran, J.W. Defining and assessing soil quality. In Defining Soil Quality for Sustainable Environment; No. 631.4 D313d; Soil Science Society of America: Madison, WI, USA, 1994; pp. 3-21.

3. Karlen, D.L.; Ditzler, C.A.; Andrews, S.S. Soil quality: Why and how? Geoderma 2003, 114, 145-156. [CrossRef]

4. Paul, E.A.; Morris, S.J.; Conant, R.T.; Plante, A.F. Does the acid hydrolysis-incubation method measure meaningful soil organic carbon pools? Soil Sci. Soc. Am. J. 2006, 70, 1023-1035. [CrossRef]

5. Plante, A.F.; Conant, R.T.; Paul, E.A.; Paustian, K.; Six, J. Acid hydrolysis of easily dispersed and microaggregate-derived silt-and clay-sized fractions to isolate resistant soil organic matter. Eur. J. Soil Sci. 2006, 57, 456-467. [CrossRef]

6. Paul, E.A.; Morris, S.J.; Böhm, J.S.; Lal, R. (Eds.) The determination of soil C pool sizes and turnover rates: Biophysical fractionation and tracers. In Assessment Methods for Soil Carbon; Advances in Soil Science; CRC Press: Boca Raton, FL, USA, 2001; pp. 193-206.

7. Gregorich, E.G.; Carter, M.R.; Angers, D.A.; Monreal, C.M.; Ellert, B.H. Towards a minimum data set to assess soil organic matter quality in agricultural soils. Can. J. Soil Sci. 1994, 74, 367-385. [CrossRef]

8. Fortuna, A.-M.; Harwood, R.R.; Paul, E.A. The effects of compost and crop rotations on carbon turnover and the particulate organic matter fraction. Soil Sci. 2003, 168, 434-444. [CrossRef]

9. Bhowmik, A.; Fortuna, A.M.; Cihacek, L.J.; Bary, A.I.; Carr, P.M.; Cogger, C.G. Potential carbon sequestration and nitrogen cycling in long-term organic management systems. Renew. Agric. Food Syst. 2017, 32, 498-510. [CrossRef]

10. Gregorich, E.G.; Beare, M.H.; Carter, M.R.; Gregorich, E.G. (Eds.) Physically uncomplexed organic matter. In Soil Sampling and Methods of Analysis, 2nd ed.; CRC Press: Boca Raton, FL, USA, 2008; pp. 607-616.

11. Fortuna, A.; Harwood, R.; Kizilkaya, K.; Paul, E.A. Optimizing nutrient availability and potential carbon sequestration in an agroecosystem. Soil Biol. Biochem. 2003, 35, 1005-1013. [CrossRef]

12. Leavitt, S.W.; Follett, R.F.; Paul, E.A. Estimation of slow- and fast-cycling soil organic carbon pools from $6 \mathrm{~N}$ $\mathrm{HCl}$ hydrolysis. Radiocarbon 1996, 38, 231-239. [CrossRef]

13. Paul, E.A.; Harris, D.; Collins, H.P.; Schulthess, U.; Robertson, G.P. Evolution of $\mathrm{CO}_{2}$ and soil carbon dynamics in biologically managed, row-crop agroecosystems. Appl. Soil Ecol. 1999, 11, 53-65. [CrossRef]

14. Gollany, H.T.; Fortuna, A.M.; Samuel, M.K.; Young, F.L.; Pan, W.L.; Pecharko, M. Soil organic carbon accretion vs. sequestration using physicochemical fractionation and CQESTR simulation. Soil Sci. Soc. Am. J. 2013, 77, 618-629. [CrossRef]

15. Martel, Y.A.; Paul, E.A. Effects of cultivation on organic matter of grassland soils as determined by fractionation and radiocarbon dating. Can. J. Soil Sci. 1974, 54, 419-426. [CrossRef]

16. Follett, R.F.; Paul, E.A.; Leavitt, S.W.; Halvorson, A.D.; Lyon, D.; Peterson, G.A. Carbon isotope ratios of great plains soils and in wheat-fallow systems. Soil Sci. Soc. Am. J. 1997, 61, 1068-1077. [CrossRef]

17. Knadel, M.; Viscarra Rossel, R.A.; Deng, F.; Thomsen, A.; Greve, M.H. Visible-near infrared spectra as a proxy for topsoil texture and glacial boundaries. Soil Sci. Soc. Am. J. 2012, 77, 568-579. [CrossRef]

18. Wander, M.M.; Traina, S.J. Organic matter fractions from organically and conventionally managed soils: II. Characterization of composition. Soil Sci. Soc. Am. J. 1996, 60, 1087-1094. [CrossRef]

19. Yang, X.M.; Xie, H.T.; Drury, C.F.; Reynolds, W.D.; Yang, J.Y.; Zhang, X.D. Determination of organic carbon and nitrogen in particulate organic matter and particle size fractions of Brookston clay loam soil using infrared spectroscopy. Eur. J. Soil Sci. 2012, 63, 177-188. [CrossRef]

20. Zhang, L.; Yang, X.; Drury, C.; Chantigny, M.; Gregorich, E.; Miller, J.; Bittman, S.; Reynolds, D.; Yang, J. Infrared spectroscopy prediction of organic carbon and total nitrogen in soil and particulate organic matter from diverse Canadian agricultural regions. Can. J. Soil Sci. 2017, 98, 77-90. [CrossRef]

21. Elliott, E.T.; Cambardella, C.A. Physical separation of soil organic matter. Agric. Ecosyst. Environ. 1991, 34, 407-419. [CrossRef]

22. Calderón, F.J.; Reeves, J.B.; Collins, H.P.; Paul, E.A. Chemical differences in soil organic matter fractions determined by diffuse-reflectance mid-infrared spectroscopy. Soil Sci. Soc. Am. J. 2011, 75, 568-579. [CrossRef] 
23. Soil Science Division Staff. Soil Survey Manual, USDA Handbook 18; Government Printing Office: Washington, DC, USA, 2017.

24. Goodman, J.M.; Morris, J.W. Physical Environments of Oklahoma; Geography of Oklahoma: Oklahoma City, OK, USA, 1977; pp. 9-25.

25. Daniel, J.A. Geology and Groundwater Resources of Canadian County, Oklahoma; Research Report GRL 1-02; USDA-ARS Grazinglands Research Laboratory: El Reno, OK, USA, 2002.

26. Mesonet, El Reno, OK, USA. Available online: http://https://www.mesonet.org (accessed on 12 September 2019).

27. Terhoeven-Urselmans, T.; Helfrich, M.K.; Flessa, M.H.; Ludwig, B. Near-infrared spectroscopy can predict the composition of organic matter in soil and litter. J. Plant Nutr. Soil Sci. 2006, 169, 168-174. [CrossRef]

28. Northup, B.K.; Daniel, J.A. Distribution of soil bulk density and organic matter along an elevation gradient in central Oklahoma. Trans. ASABE 2010, 53, 1749-1757. [CrossRef]

29. Janik, L.J.; Forrester, S.T.; Rawson, A. The prediction of soil chemical and physical properties from mid-infrared spectroscopy and combined partial least-squares regression and neural networks (PLS-NN) analysis. Chemom. Intell. Lab. Syst. 2009, 97, 179-188. [CrossRef]

30. Rossel, R.A.V.; Hicks, W.S. Soil organic carbon and its fractions estimated by visible-near infrared transfer functions. Eur. J. Soil Sci. 2015, 66, 438-450. [CrossRef]

31. Anderson, D.W.; Saggar, S.; Bettany, J.R.; Stewart, J.W.B. Particle size fractions and their use in studies of soil organic matter 1. The nature and distribution of forms of carbon, nitrogen, and sulfur. Soil Sci. Soc. Am. J. 1981, 45, 767-772. [CrossRef]

32. Anderson, D.W.; Paul, E.A. Organo-mineral complexes and their study by radiocarbon dating. Soil Sci. Soc. Am. J. 1984, 48, 298-301. [CrossRef]

33. Stenberg, B.; Rossel, R.A.V.; Mouazen, A.M.; Wetterlind, J. Visible and near infrared spectroscopy in soil science. In Advances in Agronomy; Academic Press: Cambridge, MA, USA, 2010; Volume 107, pp. 163-215.

34. Cheshire, M.V.; Dumat, C.; Fraser, A.R.; Hillier, S.; Staunton, S. The interaction between soil organic matter and soil clay minerals by selective removal and controlled addition of organic matter. Eur. J. Soil Sci. 2000, 51, 497-509. [CrossRef] 